\title{
Hydrogen from electrochemical reforming of C1-C3 alcohols using proton conducting membranes
}

\author{
F. M. Sapountzi ${ }^{\mathrm{a}}$, M.N. Tsampas ${ }^{\mathrm{b}}$, H.O.A. Fredriksson ${ }^{\mathrm{a}}$, \\ J.M. Gracia ${ }^{\mathrm{c}}$, J.W. Niemantsverdriet ${ }^{\mathrm{a}, \mathrm{c}}$
}

a SynCat@DIFFER, Syngaschem BV, P.O. Box 6336, 5600 HH, Eindhoven, The Netherlands, www.syngaschem.com

b FOM Institute DIFFER, Dutch Institute For Fundamental Energy Research, De Zaale 20, 5612 AJ, Eindhoven, The Netherlands

cSynCat@Beijing, Synfuels China Technology Co. Ltd, 1 Leyuan 2 South Street, Section C, Yanqi Economic Development Area, Beijing, 101407, China, www.syncatbeijing.com

*Corresponding author: Foteini Sapountzi, email: foteini@syngaschem.com, postal address: Syngaschem BV, P.O. Box 6336, 5600 HH, Eindhoven, The Netherlands

\begin{abstract}
This study investigates the production of hydrogen from the electrochemical reforming of short-chain alcohols (methanol, ethanol, iso-propanol) and their mixtures. High surface gas diffusion $\mathrm{Pt} / \mathrm{C}$ electrodes were interfaced to a Nafion polymeric membrane. The assembly separated the two chambers of an electrochemical reactor, which were filled with anolyte (alcohol $+\mathrm{H}_{2} \mathrm{O}$ or alcohol $\left.+\mathrm{H}_{2} \mathrm{SO}_{4}\right)$ and catholyte $\left(\mathrm{H}_{2} \mathrm{SO}_{4}\right)$ aqueous solutions. The half-reactions, which take place upon polarization, are the alcohol electrooxidation and the hydrogen evolution reaction at the anode and cathode, respectively. A standard $\mathrm{Ag} / \mathrm{AgCl}$ reference electrode was introduced for monitoring the individual anodic and cathodic overpotentials. Our results show that roughly $75 \%$ of the total potential losses are due to sluggish kinetics of the alcohol electrooxidation reaction. Anodic overpotential becomes larger as the number of $\mathrm{C}$-atoms in the alcohol increases, while a slight dependence on the $\mathrm{pH}$ was observed upon changing the acidity of the anolyte solution. In the case of alcohol mixtures, it is the largest alcohol that dictates the overall cell performance.
\end{abstract}

Keywords: alcohol electrolysis; electrochemical reforming; hydrogen production; gas diffusion electrodes; polymeric proton conductor 


\section{Introduction}

Water electrolysis can offer environmental-friendly hydrogen production, provided the required power can be supplied sustainably. Since some of the most important renewable energy sources (solar and wind) are of an intermittent nature, hydrogen production can form an important part of an energy storage strategy. Electrolysers using proton exchange polymeric membranes (PEM) offer a compact reactor design and produce high purity hydrogen at low temperatures (which is essential if the produced hydrogen is to be used for power production in PEM fuel cells) [1-4]. However, the high anodic overpotentials, caused by the sluggish kinetics of the oxygen evolution reaction, lead to significant energy losses and thus to high hydrogen production costs compared to other methods (e.g. natural gas reforming or coal gasification) [5].

An alternative and promising approach for the production of hydrogen using PEM electrolytes has emerged lately, named alcohol electrolysis or electrochemical reforming of alcohols or organic solution assisted water electrolysis [6]. The power demands during this process are significantly lower compared to water electrolysis, thus this technology can offer remarkably reduced operational costs during long-term hydrogen production [7]. Comparison of theoretical and experimental data regarding the efficiency of (i) a methanol PEM electrolyser coupled with a PEM fuel cell and (ii) a Direct Methanol Fuel Cell, has shown that under certain conditions and for specific applications (e.g. portable devices handled by humans) the first approach is more viable [8]. Moreover, energetic analysis has shown that alcohol electrolysis is advantageous compared to the catalytic alcohol reforming [9]. Additionally, methanol and ethanol can be produced from biomass, while the produced $\mathrm{CO}_{2}$ can be recaptured by living plants to regenerate the required biomass [10]. Finally, the process has potential for several applications, taking into account that short-chain alcohols are present in industrial wastewater, e.g. from Fischer-Tropsch synthesis [11] or the silicon solar cell manufacturing industry (particularly iso-propanol) [12].

Similar as in PEM fuel cells, a Membrane-Electrode Assembly (MEA) is the heart of a PEM electrolyser and consists of an anode, a cathode and a polymeric electrolyte. Polarization through an external electrical circuit, causes electrooxidation of the alcohols (or other organic compounds) at the anode of the cell. Thus, $\mathrm{CO}, \mathrm{CO}_{2}$ or other organic compounds together with protons and electrons are formed. The external circuit offers the pathway for driving electrons towards the cathode, while at the same time protons $\left(\mathrm{H}^{+}\right)$are transported to the cathode side via the polymeric 
electrolyte. Upon arriving at the cathode, protons and electrons recombine and the hydrogen evolution reaction (HER) takes place.

So far the anodic reaction, i.e. the alcohol electrooxidation, has been extensively studied in literature and the electrooxidation activities of single alcohols have been compared under both acidic and alkaline conditions. In these studies aqueous electrolytes have been used in singlechamber electrochemical reactors with a three-electrode configuration, while the electrocatalysts are typically supported on glassy-carbon substrates and not on gas diffusion supports [13-21].

The feasibility of the alcohol electrolysis concept in solid-state PEM electrolysis cells with high surface area gas diffusion electrodes has been so far validated for the cases of methanol [10,22-30], ethanol and second generation industrial bioethanol [6,29,31-36], and the concept has also been applied for hydrogen production from formic acid [37], glycerol [38-41], ethylene glycol $[29,42]$ and other diols [43].

In these investigations polymeric electrolytes (with $\mathrm{H}^{+}$or $\mathrm{OH}^{-}$conductivity) have been used and the overall process took place in PEM electrolysis cells. The effect of operational parameters (such as temperature, flow rate and alcohol concentration) has been thoroughly investigated. However, results from different studies are not directly comparable due to the different working protocols followed by each group. For instance, alcohol-containing solutions, which were supplied to the anode, were either diluted in water $[6,10,22,29,31,32,38]$ or in acidic/alkaline solutions $[27,28,39,40]$. In the case of glycerol electroreforming using $\mathrm{OH}^{-}$conducting polymeric membranes, de Paula et al [40] showed that the $\mathrm{KOH}$ concentration in the anolyte solution has an important effect on the cell's performance. Thus the anolyte's $\mathrm{pH}$ is a parameter that should not be ignored and investigation of this effect is one of the scopes of the present article.

In our study we used $\mathrm{H}^{+}$conducting polymeric electrolytes for the production of hydrogen through the electrochemical reforming of different short-chain alcohols (methanol, ethanol, isopropanol), while we investigated also the possibility of using an alcohol mixture. An alternative reactor design allowed us to quantify individual potential losses, while we also examined the role of the anolyte solution's $\mathrm{pH}$ on the performance of each step in the overall process.

Complete membrane-electrode assemblies were introduced as separators in a dual chamber electrochemical reactor, as done by Cloutier et al [25] for methanol electrolysis. Aqueous alcohol and $\mathrm{H}_{2} \mathrm{SO}_{4}$ solutions filled the reactor's anodic and cathodic compartments respectively. The halfreactions that took place upon polarization are the alcohols electrooxidation at the anode and the 
hydrogen evolution at the cathode. High surface area gas diffusion electrodes were used in our case, resembling the applicable system of PEM electrolysis; however, distinguished differences exist between our system and other PEM alcohol electrolysers used in literature:

(i) Static solution was used in our case, whereas continuous flow of reactants is typically used in PEM electrolysers. However, since our study was limited to low alcohol conversions and to short-term experiments, the batch-type operation is expected to provide qualitatively similar results with PEM electrolysis operated under continuous flow.

(ii) The hereby used electrochemical cell offers a simpler design and has significantly lower cost, thus making our system more appropriate for fundamental investigations.

(iii) The aqueous phase in our study allows the utilization of a standard $\mathrm{Ag} / \mathrm{AgCl}$ reference electrode for monitoring the anodic and cathodic overpotentials. On the contrary, utilization of reference electrodes in PEM electrolysers (and fuel cells) is still an issue, even though reliable reference electrodes have been demonstrated in the literature [44$52]$.

Our results show that the overall cell performance is mainly limited by the sluggish kinetics of the alcohol electrooxidation reaction. Anodic overpotential becomes larger as the number of Catoms in the alcohol increases, while when using alcohol mixtures the largest alcohol dictates the cell performance. The $\mathrm{pH}$, or in other words the ionic conductivity of the anolyte solution, also affects the performance.

\section{Materials and methods}

\subsection{Membrane-Electrode Assembly preparation}

A proton conducting Nafion 117 membrane with thickness 0.007 inch (Sigma Aldrich) was used as the proton-conducting electrolyte. Prior to its use, the membrane was treated by successive immersion in 15 wt $\% \mathrm{H}_{2} \mathrm{O}_{2}, 1 \mathrm{M} \mathrm{H}_{2} \mathrm{SO}_{4}$ and deionized $\mathrm{H}_{2} \mathrm{O}$ at $80^{\circ} \mathrm{C}, 2$ hours for each step. Between each treatment step, the membrane was rinsed thoroughly with deionized $\mathrm{H}_{2} \mathrm{O}$.

Commercial gas diffusion electrodes were used for the anode and the cathode, with $1 \mathrm{mg} / \mathrm{cm}^{2}$ Pt $(20 \% \mathrm{Pt} / \mathrm{C})$ loaded on carbon cloth (ElectroChem Inc.). The geometric surface area of both electrodes was $12.6 \mathrm{~cm}^{2}$. A polymer solution (Nafion perfluorinated ion-exchange resin, $5 \% \mathrm{wt}$. solution in lower aliphatic alcohols $/ \mathrm{H}_{2} \mathrm{O}$ mix, Sigma Aldrich) was applied on the surface of the 
electrodes $\left(1.5 \mathrm{mg} / \mathrm{cm}^{2}\right)$. The membrane-electrode assembly (MEA) was hot-pressed under 0.2 metric ton $/ \mathrm{cm}^{2}$ at $120^{\circ} \mathrm{C}$ for $3 \mathrm{~min}$.

\subsection{Experimental setup and methods}

The experiments were carried out in a dual-chamber, separated electrochemical reactor made from borosilicate glass (Pine Research Instrumentation), shown schematically in Figure 1a. The two chambers were filled with $25 \mathrm{ml}$ of the anolyte and catholyte solutions respectively and were hold together using a spherical metallic clamp. Appropriate caps were fitted with polymeric (polyether ether ketone-PEEk) plugs and allowed the insertion of gas inlet/outlet tubes and of the reference electrode $\mathrm{The} \mathrm{Ag} / \mathrm{AgCl}$ low profile reference electrode (Pine Research Instrumentation). with the reference section filled with $\mathrm{KCl}$ gel was inserted in the catholyte chamber. The MEA was clamped between the two chambers, and appropriate, spherical joint o-rings were used for sealing of the cell. Thin Ti wires $(0.25 \mathrm{~mm}$, Alfa Aesar) were attached at each side of the MEA for enabling the current collection.

During all experiments, the catholyte chamber was filled with $0.3 \mathrm{M} \mathrm{H}_{2} \mathrm{SO}_{4}$ solution. Methanol, ethanol and iso-propanol (Sigma Aldrich, $>99.5 \%$ ) were introduced in the anolyte at different concentrations, after mixing with proper amounts of either deionized $\mathrm{H}_{2} \mathrm{O}$ or $0.2 \mathrm{M}$ $\mathrm{H}_{2} \mathrm{SO}_{4}$. Between studies of different alcohols, the MEA was washed by immersion in ultrapure water.

The experiments took place at room temperature. Polarization data were collected using an Ivium Vertex potentiostat, equipped with an integrated impedance interface for carrying out the Electrochemical impedance spectroscopy (EIS) measurements. The cell impedance was measured using a frequency range from $10 \mathrm{kHz}$ to $10 \mathrm{mHz}$ with a potential amplitude of $10 \mathrm{mV}$. Potentialcurrent data were obtained by polarizing the cell (anode-cathode). At the same time, the individual potentials of the anode and the cathode versus the $\mathrm{Ag} / \mathrm{AgCl}$ reference electrode were recorded using an IVIUM high impedance differential amplifier (Figure 1b). All overpotential values are calculated versus the potential at zero cell current. Given potential values are IR-free; corrections were made using the ohmic resistance values from EIS spectra, which were recorded between anode-cathode, anode-reference and cathode-reference. 


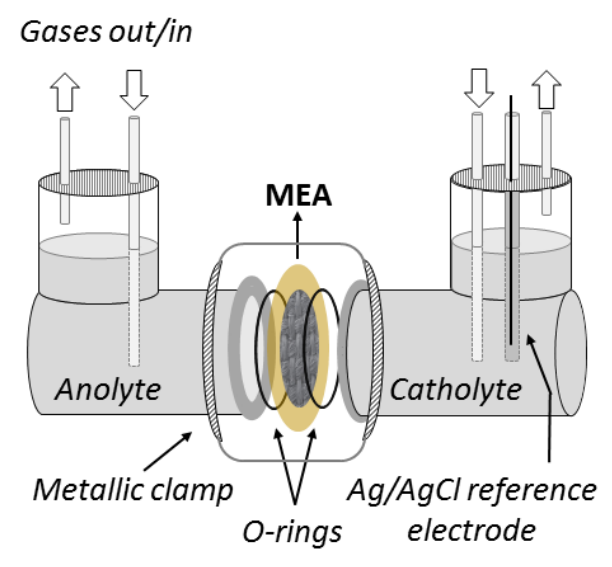

(a)

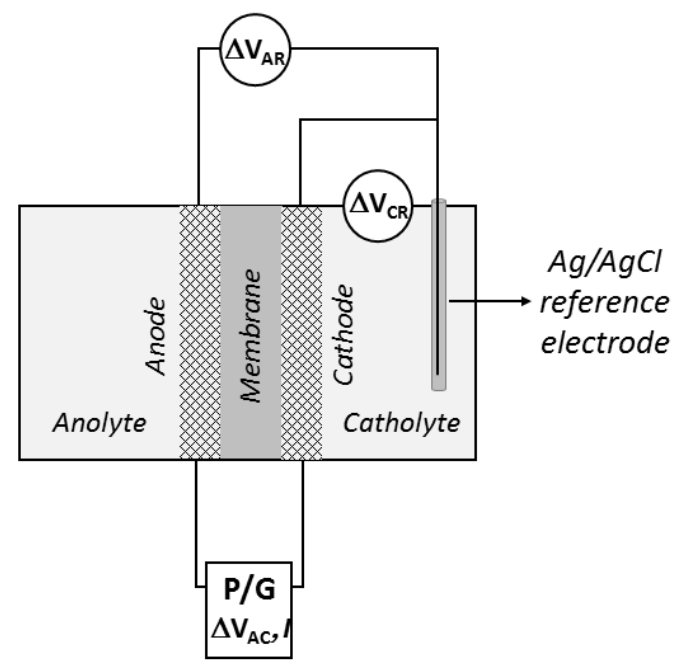

(b)

Figure 1. (a) Schematic representation of the electrochemical cell. The two chambers are separated by the MEA and a metallic clamp is used to hold together the assembly. (b) The corresponding electrical circuit is shown. The potentials of anode and cathode vs the $\mathrm{Ag} / \mathrm{AgCl}$ reference electrode, $\Delta V_{A R}$ and $\Delta V_{C R}$ respectively, are measured and used for the calculation of the anodic and cathodic overpotentials. A potentiostat/galvanostat $(\mathrm{P} / \mathrm{G})$ is used for applying constant cell potentials between anode and cathode $\left(\Delta V_{A C}\right)$ while also measures the cell current, I.

\section{Results and discussion}

\subsection{Deconvolution of the overpotential components}

The performance of the cell during electrochemical reforming of alcohols was evaluated by varying linearly the cell's potential (sweep rate $10 \mathrm{mV} / \mathrm{s}$ ) and recording the cell current. As the cell is polarized, alcohol electrooxidation reactions take place at the anode producing $\mathrm{H}^{+}$and several C-containing products (discussed in section 3.3). The thus produced $\mathrm{H}^{+}$transport through the polymeric electrolyte, while the hydrogen evolution reaction (HER) takes place at the cathode. The corresponding results during forward polarization scans are presented in Figure 2; in all cases the anolyte contained 5.5 $\mathrm{M}$ of each alcohol $+0.2 \mathrm{M} \mathrm{H}_{2} \mathrm{SO}_{4}$ (diluted in water).

Figure 2 indicates that at standard applied overpotentials $(\eta)$, smaller currents are obtained (i.e. lower reaction rates) as the number of $\mathrm{C}$-atoms in the alcohol increases. A similar trend has been also reported in direct alcohol fuel cells (DAFCs) with proton conducting electrolytes [53,54]. However, one should take into account that the total cell potential losses are not only due to the 
slow electrooxidation of alcohols (anodic overpotential); they can in principle be also partly due to slow hydrogen evolution reaction (cathodic overpotential), slow proton transport through the Nafion membrane (ohmic overpotential) and poor mass transfer of the reactants/products to/from the catalyst-electrode-gas three phase boundaries (concentration overpotential). The hereby used reactor design enables us to use a standard reference electrode and thus allows us to deconvolute the contribution of each of these processes to the total potential losses.

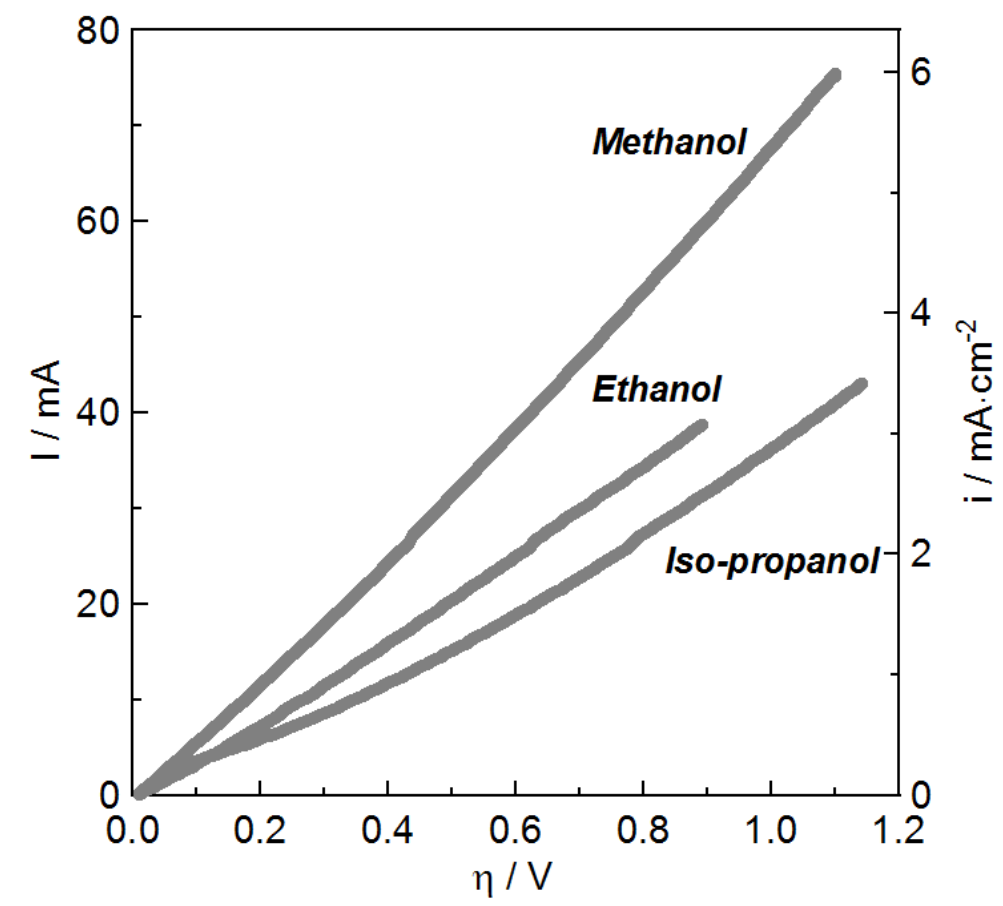

Figure 2. Dependence of current (left) and current density (right) on the applied cell overpotential (i.e. versus the potential at zero current). Data correspond to the forward scans of linear sweep voltammograms obtained with methanol, ethanol and iso-propanol. Sweep rate: $10 \mathrm{mV} / \mathrm{s}$. Anolyte: $5.5 \mathrm{M}$ alcohol $+0.2 \mathrm{M}$ $\mathrm{H}_{2} \mathrm{SO}_{4}$ in $\mathrm{H}_{2} \mathrm{O}$.

According to the polarization curves (figure 2), no limiting current was reached in the present study, thus we can safely consider that the concentration overpotential is negligible compared to the activation and ohmic overpotentials. This also verifies that the cell operation was not disturbed by poor mass transfer. The anodic and cathodic potential losses were determined by means of the $\mathrm{Ag} / \mathrm{AgCl}$ reference electrode, which allowed for continuously monitoring the potentials of the anode and cathode. Ohmic losses were quantified via EIS measurements. Figures 3a-3c show the corresponding results of overpotential deconvolution for the cases of methanol, ethanol and iso- 
propanol. The total cell overpotential, $\eta$, is shown together with its anodic $\left(\eta_{a n}\right)$, cathodic $\left(\eta_{\text {cath }}\right)$ and ohmic $\left(\eta_{o h m}\right)$ components. It is clearly shown that in all cases the overall overpotential mainly ( $75 \%)$ originates from the sluggish kinetics of the anodic reaction (alcohol electrooxidation); proton transport through the electrolytic membrane has a smaller contribution while the cathodic overpotential is negligible in all cases.

It is well-known in literature that Nafion membranes are permeable to alcohols $[53,55,56]$. For this reason DAFCs which operate at high current densities suffer from large cathodic overpotentials, caused by the blocking of the cathodic active sites by the alcohol molecules. The absence of cathodic overpotentials observed in our case (below $30 \mathrm{mV}$ ) indicates that even if alcohol crossover occurs, there is still a sufficient number of cathodic active sites available to carry out the HER. According to Tamaki et al [56] the coverage of cathodic catalytic sites by alcohols has a negligible effect to HER when DAFCs operate at low current densities, since the few available catalytic sites are still enough to carry out the fast hydrogen evolution. However, a dramatic increase in the cathodic overpotential is observed at high current densities (above 200 $\mathrm{mA} / \mathrm{cm}^{2}$ ). The current densities obtained with our cell are much lower than this threshold value, which justifies the observed negligible cathodic overpotentials.

Figure $3 \mathrm{~d}$ gives a comparison of the anodic overpotentials when different alcohols were supplied to the cell. It appears that the higher the molecular weight of the alcohol, the slower is its electrooxidation rate. Fundamental studies on the electrooxidation of aliphatic alcohols carried out in the aqueous phase have shown also an activity trend of methanol>ethanol>iso-propanol $[37,52,53]$. Based on literature, as the number of $\mathrm{C}$-atoms in the alcohol increases, the overall kinetics of alcohol electrooxidation become slower, due to the formation of strongly adsorbed intermediates and to the need for breaking the $\mathrm{C}-\mathrm{C}$ bond [57-59]. These features will be discussed in section 3.3 of the present manuscript. 


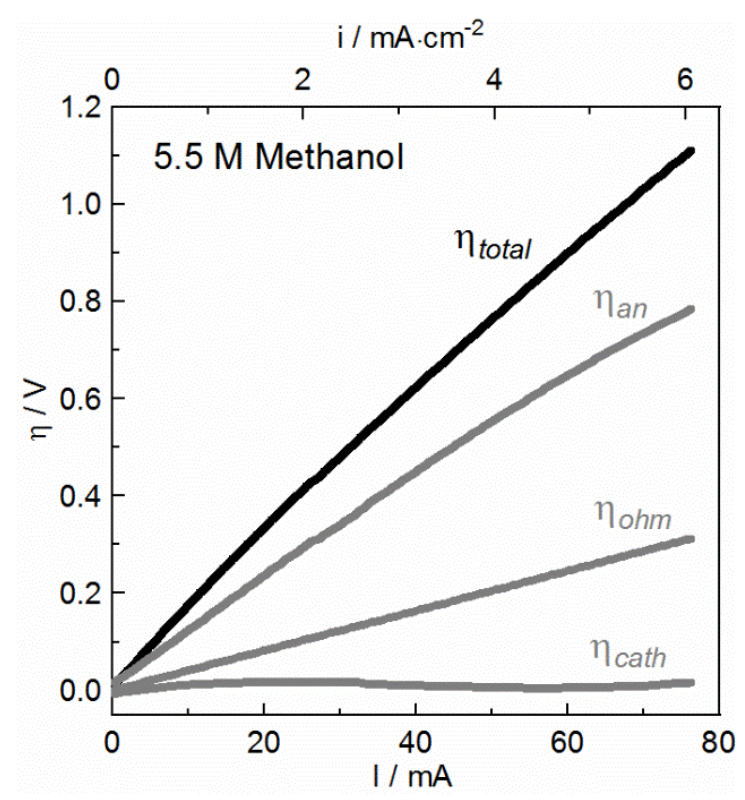

(a)

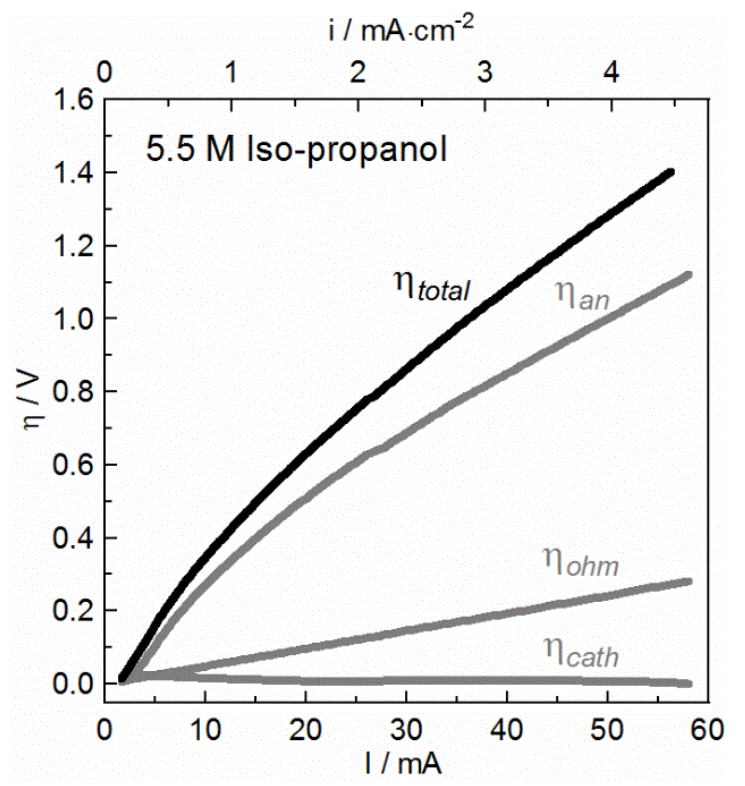

(c)

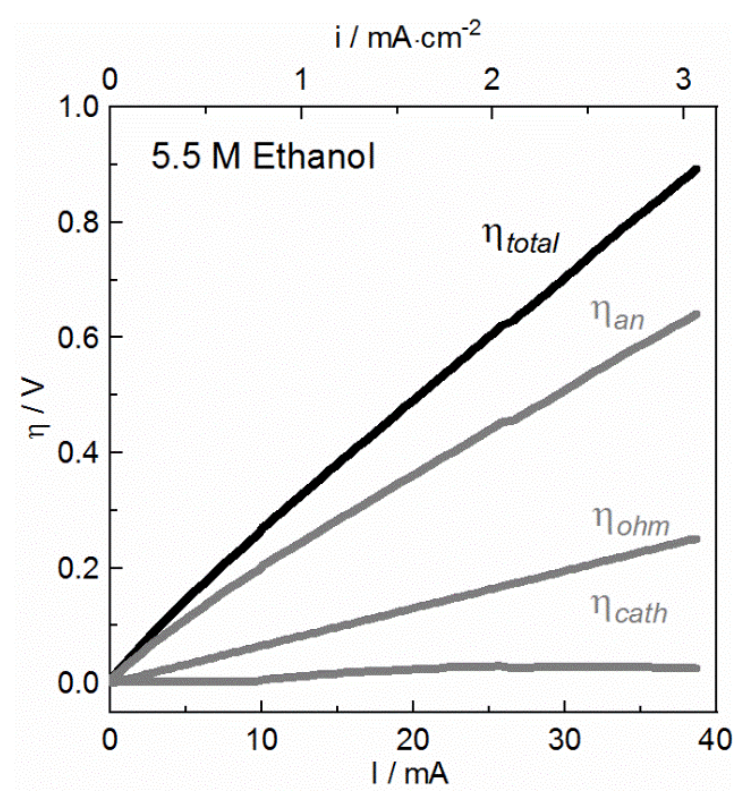

(b)

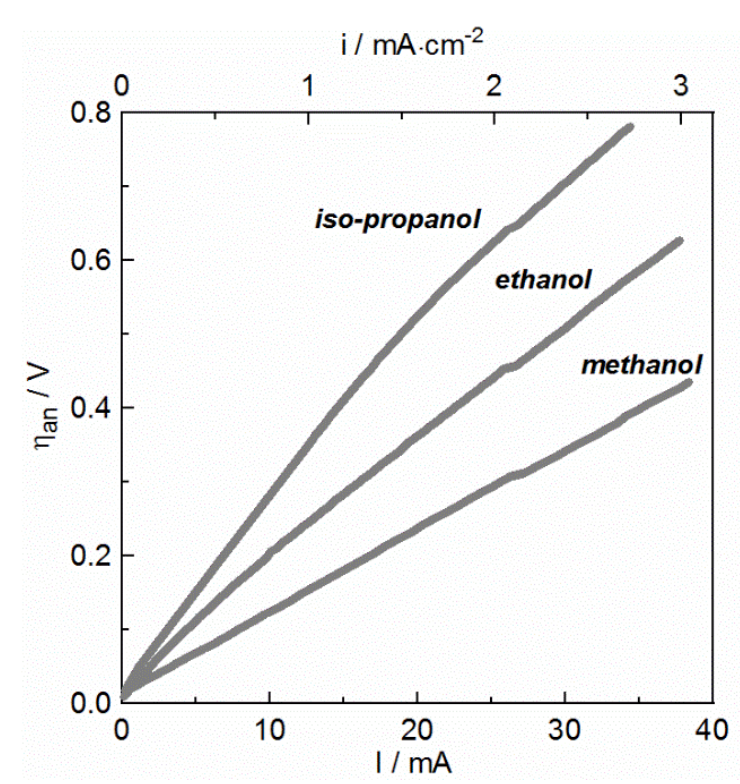

(d)

Figure 3. (a), (b) and (c): Effect of the cell current on the total cell overpotential and on the anodic, cathodic and ohmic overpotentials for (a) methanol, (b) ethanol, (c) iso-propanol. (d) Anodic overpotentials for different alcohols (zoom at currents below $40 \mathrm{~mA}$ ). Anolyte: $5.5 \mathrm{M}$ alcohol $+0.2 \mathrm{M} \mathrm{H}_{2} \mathrm{SO}_{4}$ in $\mathrm{H}_{2} \mathrm{O}$. Forward scans are presented. 
Ohmic overpotentials were quantified from Electrochemical Impedance Spectroscopy measurements carried out at open-circuit conditions and which are presented in the form of Nyquist plots (Figure 4). The main characteristics of the EIS spectra are in good agreement with those reported by Ju et al. [6] during PEM ethanol electrolysis on PtSn anodes. For all cases two semicircles were observed in the Nyquist plots, which can be related to the cathodic and anodic reactions respectively. Our results indicate that regardless of the kind of alcohol, the first semicircle exhibits its maximum at $4 \mathrm{kHz}$. The appearance of the second semicircle is observed at the low frequency region.

The total cell resistance can be derived from the intersect of the first semicircle with the horizontal axis. The determined values are 4.1, 6.5 and 5.0 $\Omega$ for methanol, ethanol and isopropanol respectively. These values correspond to the summation of the membrane resistance, the interfacial resistance in the MEA and the resistance of the current collectors and the wires in the MEA and are similar to ohmic values reported for PEM fuel cells and electrolysers operated at low temperatures $[44,60]$. Note that the ohmic component shows only a slight dependence on the kind of alcohol supplied to the cell. The observed differences can be attributed either to the protonic conductivity of Nafion membranes being affected by the presence of different alcohols [61] or to the different extent of Nafion swelling in presence of alcohols [62-64], which can accordingly affect the interfacial resistances.

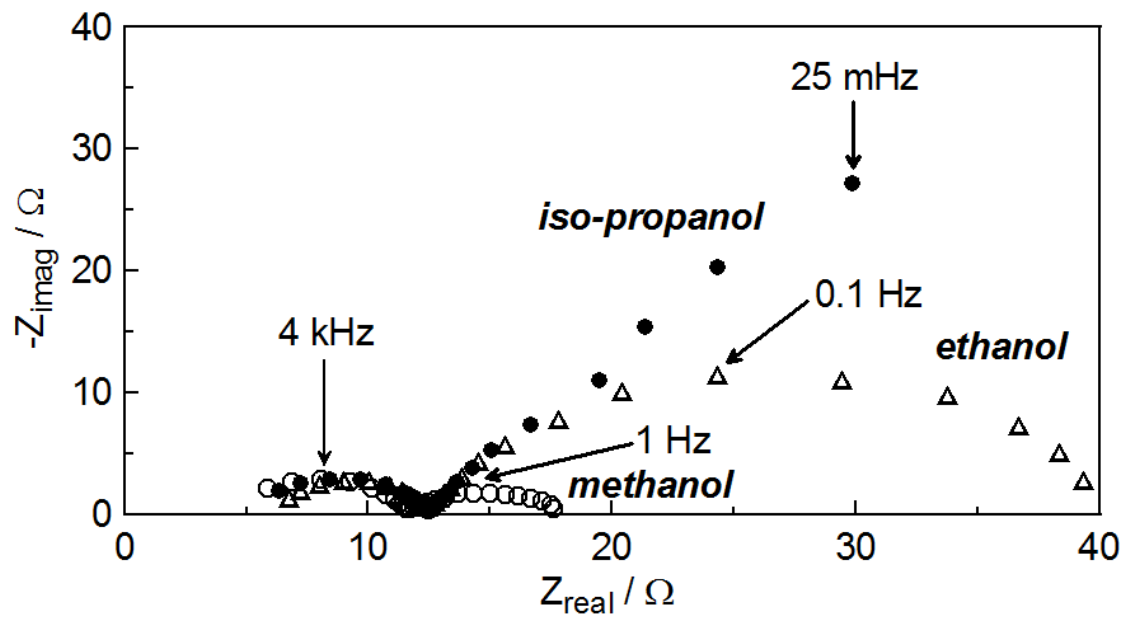

Figure 4. Nyquist spectra of the cell at open-circuit conditions with different alcohols. Anolyte: $5.5 \mathrm{M}$ alcohol $+0.2 \mathrm{M} \mathrm{H}_{2} \mathrm{SO}_{4}$ in $\mathrm{H}_{2} \mathrm{O}$. 
Moreover, according to figure 4, the first semicircle (at higher frequencies) is always smaller than the second semicircle (at lower frequencies). The cathodic charge transfer resistance (determined by the difference between the high and low frequency intercepts of the first semicircle with the $\mathrm{x}$-axis on the Nyquist plots), is independent of the nature of the alcohol and equals to 7.4 $\Omega$ in all cases. This is in accordance with the negligible cathodic overpotential (figure 3 ) indicating that HER is a facile reaction. In contrast, the second semicircle becomes significantly larger as the number of C-atoms in the alcohols increases (figure 4), which is in line with the trend of the anodic overpotential (figure $3 \mathrm{~d}$ ).

As shown in figure 5a, changes in the alcohol concentration and polarization of the cell have an effect only on the high-frequency semicircle of the Nyquist plots. By increasing the applied potential, the alcohols electrooxidation gets faster and thus the second semicircle becomes smaller (figure 5a, bottom). Furthermore, an inductive loop is observed over the low frequency and under polarization. Similar inductive loops have been reported in literature of alcohols electrooxidation $[53,65,66]$ and are most likely associated with the relaxation of reaction products (or intermediate species) which are adsorbed on the surface of the anode.

By increasing the alcohol concentration, the second semicircle becomes larger due to an increase in the resistance of the electrode reaction (figure 5a, top). This is corroborated by the observed decreased cell's performance at higher alcohol concentrations (figure 5b). Literature studies on ethanol electrochemical reforming in PEM reactors have indicated a volcano-type behavior in the current vs alcohol concentration dependence, with a maximum current obtained at 6.0 $\mathrm{M}$ ethanol [31,32]. In the present case, the maximum current was obtained only at $2.0 \mathrm{M}$ ethanol concentration. Thus, the observed decrease in electrocatalytic activity when ethanol concentration ranges between 2.0 and $5.5 \mathrm{M}$ corresponds only to the right region of the volcano curve. This shift of the maximum to lower ethanol concentrations is due to the different nature of the anodic electrocatalyst. It is well demonstrated that the Pt-Ru electrodes, which were used by Caravaca et al. [31,32] exhibit higher resistance to poisoning compared to Pt which was used in the present study. Pt-Ru then can in principle tolerate operation under higher alcohol concentrations, while Pt gets severely poisoned at relatively low ethanol concentrations $[67,68]$. 


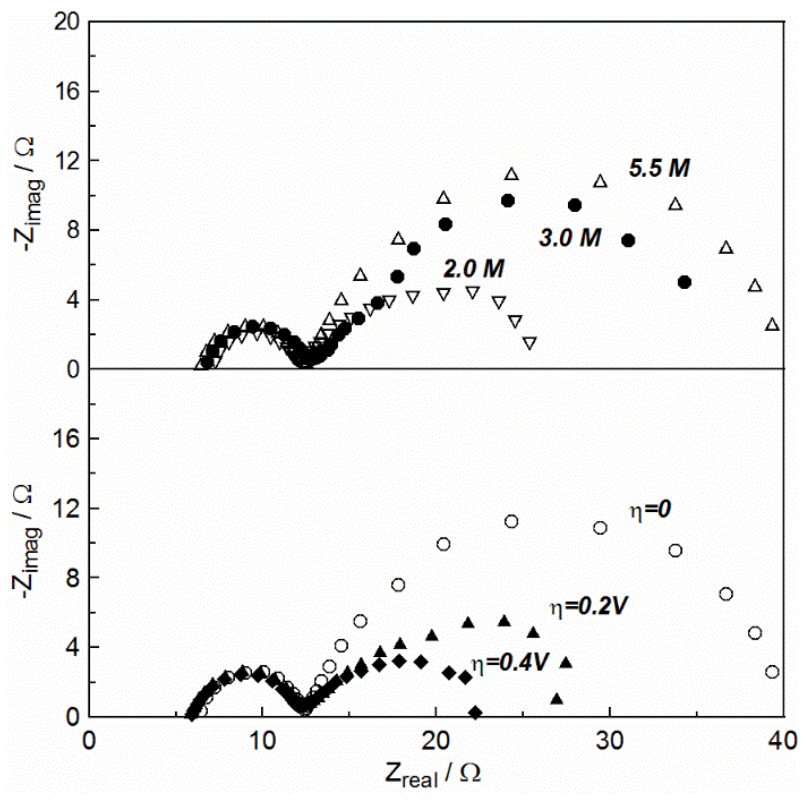

(a)

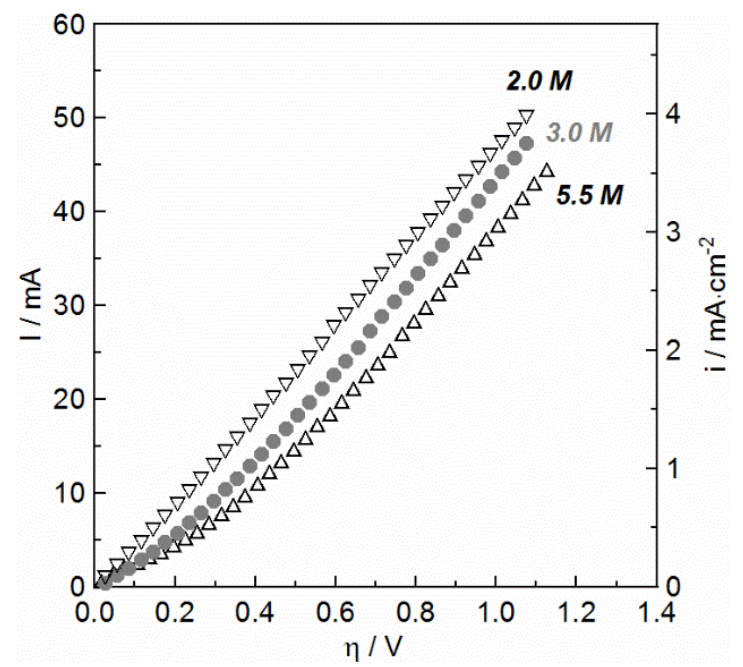

(b)

Figure 5. (a): Nyquist spectra of the cell recorded: (top) at open-circuit conditions for different ethanol concentrations, (bottom) at open-circuit and under different applied overpotentials with $5.5 \mathrm{M}$ ethanol + $\mathrm{H}_{2} \mathrm{O}$. (b): Polarization data with different ethanol concentrations diluted in water.

\subsection{Effect of the $\mathrm{pH}$ in the anolyte solution}

In order to examine the effect of the $\mathrm{pH}$ in the anolyte solution, two different series of experiments were carried out having different $\mathrm{pH}$ values in the anolyte solution: (i) acidic 
conditions where the alcohols were mixed with $0.2 \mathrm{M} \mathrm{H}_{2} \mathrm{SO}_{4}$, indicated as " $\mathrm{pH}=0.4$ " (ii) neutral conditions where the alcohols were mixed with $\mathrm{H}_{2} \mathrm{O}$ indicated as " $\mathrm{pH}=7.0$ ". Note that the $\mathrm{pH}$ values refer to the as-produced anolyte solutions. The sulfonate groups in the Nafion membrane, however, are strongly acidic, especially when the polymer is hydrated [69] and thus the actual conditions in the vicinity of the electrocatalytically active sites in case (ii) are slightly acidic. However, for convenience, we use the terms "neutral conditions" and " $\mathrm{pH}=7.0$ " throughout this article, since they refer to the bulk anolyte solutions.

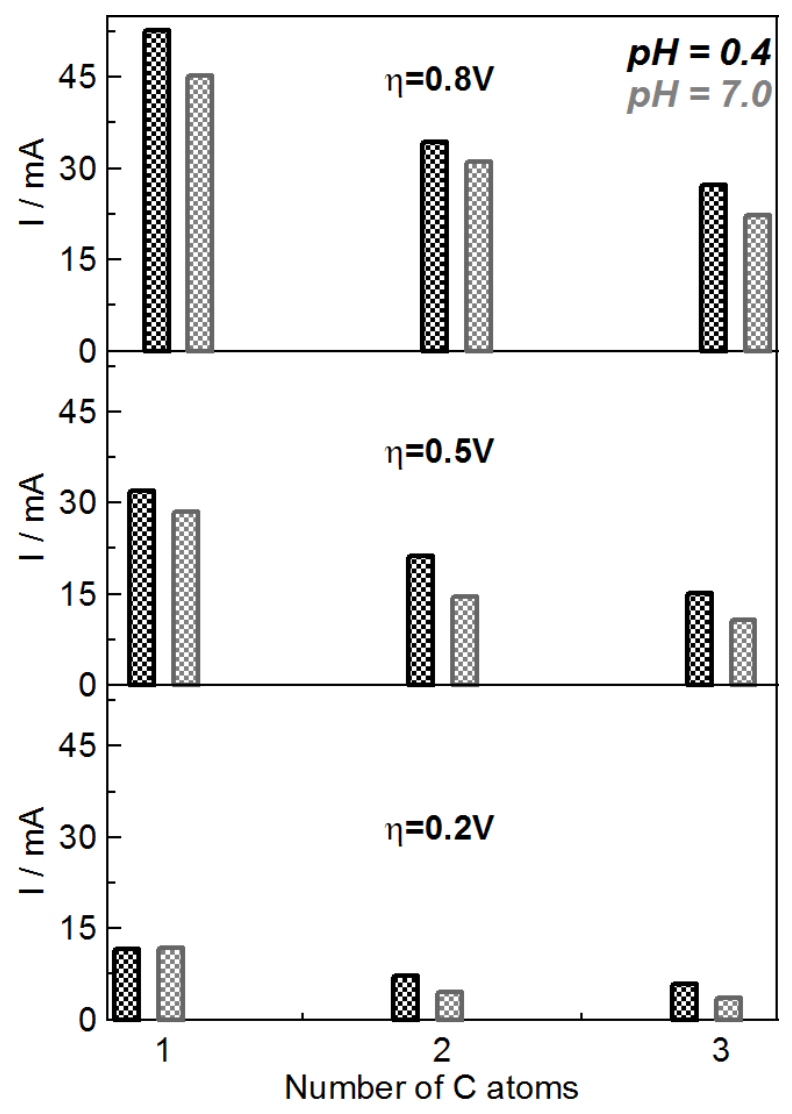

Figure 6. Cell's current for different values of overpotential, pH and number of C-atoms in the alcohol.

Figure 6 summarizes the effect of the alcohol's nature and of the surrounding $\mathrm{pH}$ on the electrocatalytic activity when the cell operates under small and large overpotentials. In general, the performance of the cell is affected by the $\mathrm{pH}$ in the way that higher currents were obtained under strongly acidic conditions and this trend is more pronounced when the cell operates under 
large overpotentials. Figure 7 presents the evolution of the several overpotential components when the cell operates under ethanol in acidic and neutral conditions.

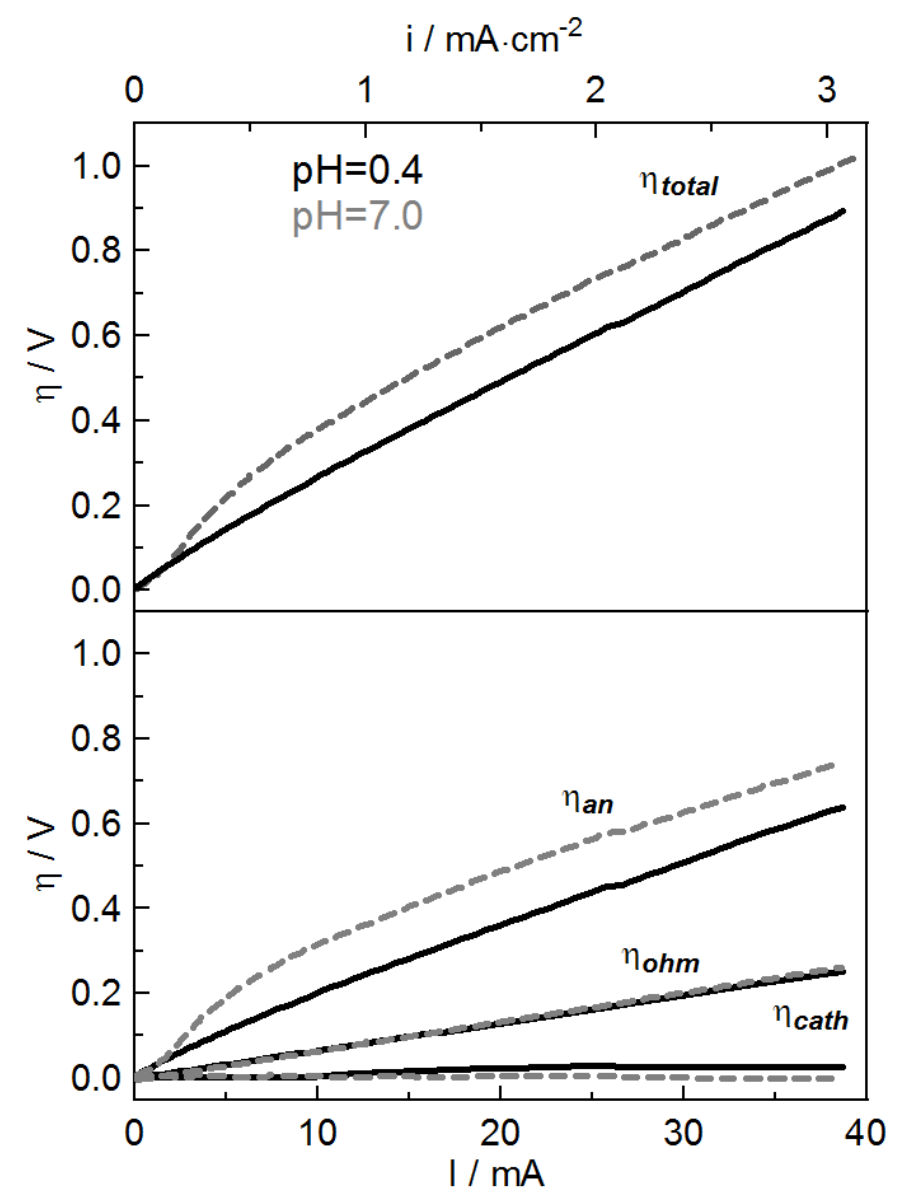

Figure 7. Effect of the cell current (bottom x-axis) and current density (top x-axis) on the total cell overpotential and on the anodic, cathodic and ohmic overpotentials during ethanol electroreforming. Black and grey curves correspond to different anolyte solutions. Black, solid: $5.5 \mathrm{M}$ ethanol $+0.2 \mathrm{M} \mathrm{H}_{2} \mathrm{SO}_{4}$ in $\mathrm{H}_{2} \mathrm{O}(\mathrm{pH}=0.4)$. Grey, dashed: $5.5 \mathrm{M}$ alcohol in $\mathrm{H}_{2} \mathrm{O}(\mathrm{pH}=7.0)$. The curves correspond to the forward scans.

Fundamental electrochemical studies have shown that the electrooxidation of alcohols is greatly affected by changing the $\mathrm{pH}$ from acidic to alkaline, performing better in alkaline environments [70-72]. Our work was only focused on $\mathrm{pH}$ variations in the anolyte solution within the acidic regime.

Regarding ohmic losses, it has been reported that the conductivity of Nafion is affected by the $\mathrm{pH}$ [73], while also the swelling of Nafion due to the presence of alcohols is more pronounced in 
presence of water (compared to $\mathrm{H}_{2} \mathrm{SO}_{4}$ ) [63] and thus can increase interfacial resistances. In our case the overpotential deconvolution indicated negligible variation of the cell resistance due to changes in the $\mathrm{pH}(6.5 \Omega$ in $\mathrm{pH}=0.4$ vs $6.6 \Omega$ in $\mathrm{pH}=7)$. It thus appears that the decrease in the cell's performance at neutral conditions is the result only of slower alcohol electrooxidation kinetics (anodic reaction). The enhanced kinetics at $\mathrm{pH}=0.4$ could be attributed to the ionic conductivity of the anolyte solution. The ions, which are present in the acidic solution, interact with the catalyst surface and thus lead to an extended reaction zone by providing an extra pathway for the protons to move.

\subsection{Anodic reactions}

The large anodic overpotentials (Figure 3d) and the large anodic impedance semicircles (Figure 4) observed in our study for the case of iso-propanol indicate that the anodic reaction rates are slower for heavier alcohols. This behavior can be related to the formation of poisonous intermediate species, to difficulties in the scission of the $\mathrm{C}-\mathrm{C}$ bonds or to the competitive adsorption of alcohols and water where the steric effects are expected to be more pronounced for larger alcohol molecules.

During operation, several half-reactions take place at the anode. Apart from the alcohol-related reactions, water adsorption takes also place forming hydroxyl adsorbed species, which then participate in alcohol electrooxidation as discussed below. Water adsorption follows the reaction:

$$
\mathrm{H}_{2} \mathrm{O} \rightarrow \mathrm{OH}_{\text {ads }}+\mathrm{H}^{+}+\mathrm{e}^{-}
$$

For the case of methanol, the main intermediate species formed is $\mathrm{CO}$, which is subsequently oxidized to $\mathrm{CO}_{2}$ by $\mathrm{OH}_{\text {ads, }}$, as described in reactions (2) and (3) [70]:

$$
\begin{aligned}
& \mathrm{CH}_{3} \mathrm{OH} \rightarrow \mathrm{CO}_{\mathrm{ads}}+4 \mathrm{H}^{+}+4 \mathrm{e}^{-} \\
& \mathrm{CO}_{\mathrm{ads}}+\mathrm{OH}_{\mathrm{ads}} \rightarrow \mathrm{CO}_{2}+\mathrm{H}^{+}+\mathrm{e}^{-}
\end{aligned}
$$

However, it has been proposed that other intermediates can be formed as well, according to reactions (4) and (5) [74,75]:

$$
\begin{aligned}
& \mathrm{CH}_{3} \mathrm{OH} \rightarrow \mathrm{COH}_{\mathrm{ads}}+3 \mathrm{H}^{+}+3 \mathrm{e}^{-} \\
& \mathrm{CH}_{3} \mathrm{OH} \rightarrow \mathrm{CH}_{3} \mathrm{O}_{\text {ads }}+\mathrm{H}^{+}+\mathrm{e}^{-}
\end{aligned}
$$

For the case of ethanol, adsorbed $\mathrm{CO}, \mathrm{C}_{1}$ and $\mathrm{C}_{2}$ hydrocarbon residues have been reported as the major adsorbed intermediates, formed during the dissociative adsorption of ethanol according to reaction (6) $[67,76-78]$ : 


$$
\mathrm{CH}_{3} \mathrm{CH}_{2} \mathrm{OH} \rightarrow \mathrm{CH}_{\mathrm{x}, \text { ads }}+\mathrm{CO}_{\text {ads }}
$$

Acetaldehyde is a major product of ethanol electrooxidation and its formation does not involve water molecules (reaction (7)). Typically, acetaldehyde is further oxidized to acetic acid according to reaction (8). Ethanol electrooxidation to $\mathrm{CO}_{2}$ can also take place at higher applied voltages. The most typical reactions that can take place in the case of ethanol are [67]:

$$
\begin{aligned}
& \mathrm{CH}_{3} \mathrm{CH}_{2} \mathrm{OH} \rightarrow \mathrm{CH}_{3} \mathrm{CHO}+2 \mathrm{H}^{+}+2 \mathrm{e}^{-} \\
& \mathrm{CH}_{3} \mathrm{CHO}+\mathrm{H}_{2} \mathrm{O} \rightarrow \mathrm{CH}_{3} \mathrm{COOH}+2 \mathrm{H}^{+}+2 \mathrm{e}^{-} \\
& \mathrm{CH}_{3} \mathrm{CH}_{2} \mathrm{OH}+5 \mathrm{H}_{2} \mathrm{O} \rightarrow 2 \mathrm{HCO}_{3}^{-}+14 \mathrm{H}^{+}+14 \mathrm{e}^{-} \\
& \mathrm{CH}_{3} \mathrm{CH}_{2} \mathrm{OH}+5 \mathrm{H}_{2} \mathrm{O} \rightarrow 2 \mathrm{CO}_{3}^{2-}+16 \mathrm{H}^{+}+16 \mathrm{e}^{-} \\
& \mathrm{CH}_{3} \mathrm{CH}_{2} \mathrm{OH}+3 \mathrm{H}_{2} \mathrm{O} \rightarrow 2 \mathrm{CO}_{2}+12 \mathrm{H}^{+}+12 \mathrm{e}^{-}
\end{aligned}
$$

According to literature $[76,79]$, in contrast to primary alcohols, the adsorption of iso-propanol on $\mathrm{Pt}$ is non-dissociative. During cell operation, formation of acetone from iso-propanol takes place according to reaction (12); water does not participate in this reaction [80]:

$$
\left(\mathrm{CH}_{3}\right)_{2} \mathrm{CHOH} \rightarrow\left(\mathrm{CH}_{3}\right)_{2} \mathrm{CO}+2 \mathrm{H}^{+}+2 \mathrm{e}^{-}
$$

As a further step, acetone electrooxidation to $\mathrm{CO}_{2}$ can also take place [79] via reaction (13):

$$
\left(\mathrm{CH}_{3}\right)_{2} \mathrm{CO}+5 \mathrm{H}_{2} \mathrm{O} \rightarrow 3 \mathrm{CO}_{2}+16 \mathrm{H}^{+}+16 \mathrm{e}^{-}
$$

For the simplicity of the discussion, the polarization curves presented so far in this manuscript correspond only to the forward scans of polarization. For the cases of methanol and ethanol, the forward and backward scans are identical; however, for the case of iso-propanol the voltammogram contains hysteresis features (Figure 8). The current during the backward scan is higher than in the forward scan, while two oxidation peaks are also observed under acidic conditions.

Complex voltammograms have been reported in the literature of electrooxidation of alcohols and they have been attributed to changes on the catalyst surface [81]. According to Shell et al. $[82,83]$, oxygenated Pt species formed under polarization can lead either to the oxidation of intermediate species or to the formation of platinum oxides, while according to Varela and Krischer [84] surface roughening/relaxation occurs. In order to verify whether the observed behaviour is linked with an oscillatory behaviour or with an activated steady-state, chronoamperometry experiments were performed by applying standard overpotentials for $15 \mathrm{~min}$ (not shown here); no oscillations were observed in the current evolution over time. 


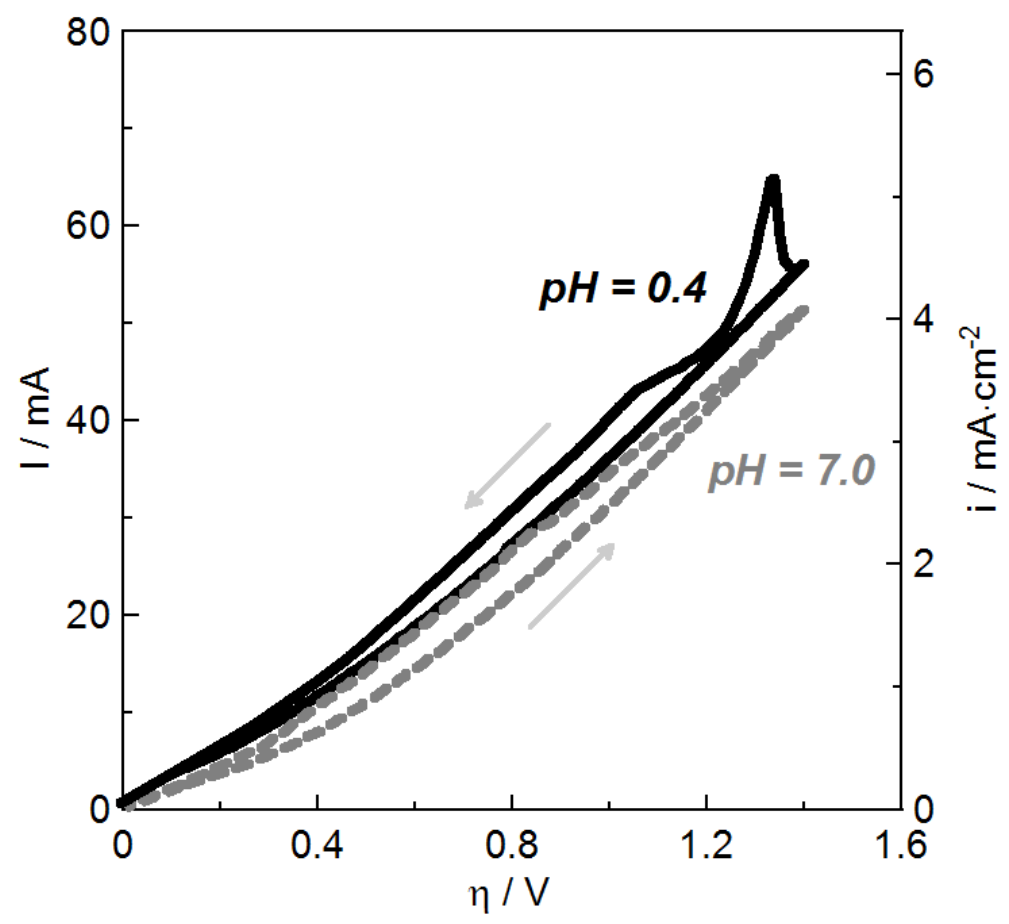

Figure 8. Linear sweep voltammograms, sweep rate: $10 \mathrm{mV} / \mathrm{s}$. Forward and backward scans obtained with iso-propanol solutions in $\mathrm{H}_{2} \mathrm{SO}_{4}$ (black solid line) and $\mathrm{H}_{2} \mathrm{O}$ (grey dashed line). Anolyte: $5.5 \mathrm{M}$ iso-propanol in $\mathrm{H}_{2} \mathrm{O}$.

Hysteresis phenomena in our study were observed only with iso-propanol. This could be related to differences between primary alcohols and secondary alcohols; e.g. dissociative vs nondissociative adsorption, easier cleavage of the $\mathrm{C}-\mathrm{C}$ bond when an oxygen atom is present in the $\mathrm{C} 1$ position [76]. Finally, since the nature of intermediate species is different for each alcohol used, it is very likely that acetone, the product for the case of iso-propanol, is adsorbed on the catalytically active sites, hindering further adsorption and reaction of iso-propanol and thus causing a poisoning effect which leads to smaller cell currents [85]. After reaching the upper potential limit, changes in the Pt oxidation state may affect the adsorption strength of iso-propanol, acetone and water and this could possibly lead to the higher electrocatalytic rates during the backward scan. Competition for the adsorption of (bi)sulfate anions is expected also to play a significant role [77] and could be linked to the observed differences between neutral and acidic media. Further experiments with acetone and n-propanol are in progress and are expected to elucidate the origin of these hysteresis phenomena. 


\subsection{Alcohol mixtures}

Apart from utilizing anolyte solutions with each alcohol individually as commonly done in literature, experiments were also carried out where an alcohol mixture was supplied to the anode . The molar concentration ratio of methanol:ethanol:iso-propanol was selected as 1.9:1.4:1.0, which resembles the composition of Fischer-Trospch wastewater [11]. The total alcohol concentration in the anolyte solution was $5.5 \mathrm{M}\left(2.4 \mathrm{M}\right.$ methanol, $1.8 \mathrm{M}$ ethanol, 1.3 $\mathrm{M}$ iso-propanol in $\left.\mathrm{H}_{2} \mathrm{O}\right)$.

The polarization curve obtained using the alcohol mixture is presented in Figure 9, while the curves corresponding to individual alcohols are also shown for comparison. Three main features were observed. First, the cell performance in the alcohol mixture is lower compared to the cases of supplying methanol or ethanol individually. Thus, one could conclude that when the alcohol mixture is supplied to the anode, the rate of electrooxidation is dictated by the iso-propanol. Second, no hysteresis was observed with the alcohol mixture. Third, the polarization curve with the alcohol mixture (identical forward and backward scans) is identical to that of the backward scan obtained with iso-propanol. It is likely that the presence of methanol and ethanol promote the desorption of acetone and thus ensure the availability of active sites for iso-propanol adsorption.

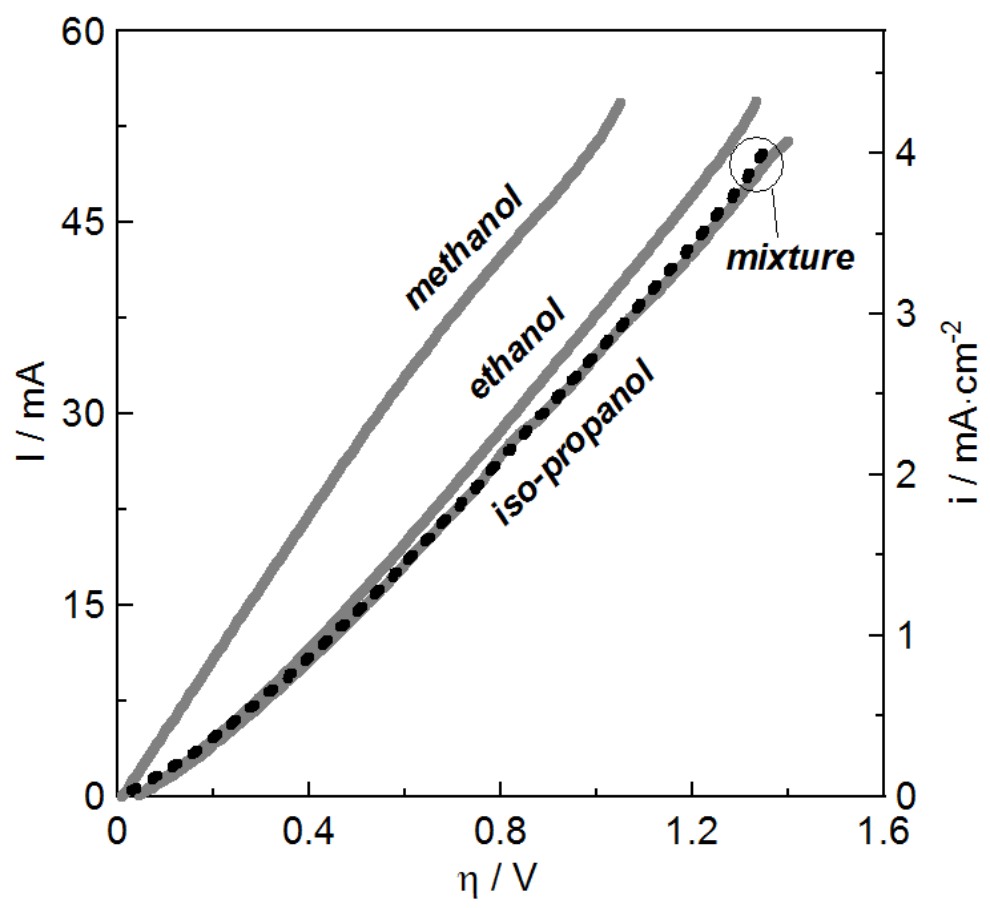

Figure 9. Linear sweep voltammograms, sweep rate: $10 \mathrm{mV} / \mathrm{s}$. Backward scans obtained with the alcohol mixture (dashed black line), methanol, ethanol and iso-propanol (solid grey lines). Anolyte: $5.5 \mathrm{M}$ alcohol in $\mathrm{H}_{2} \mathrm{O}$. 


\section{Conclusions}

The electrochemical reforming of short chain alcohols (methanol, ethanol, iso-propanol) and their mixtures was investigated for hydrogen production. A membrane electrode assembly with gas diffusion $\mathrm{Pt} / \mathrm{C}$ electrodes and a polymeric proton conducting membrane was introduced in a dual chamber electrochemical reactor filled with aqueous solutions. Deconvolution of the overpotential components by means of an $\mathrm{Ag} / \mathrm{AgCl}$ reference electrode indicated that the overall cell performance is mainly affected by the sluggish anodic reaction (i.e. alcohol electrooxidation). Cell currents under standard applied potentials were found to decrease as the number of $\mathrm{C}$-atoms in the alcohol increases, while in the case of alcohol mixtures the heaviest alcohol dictates the cell performance. The $\mathrm{pH}$ in the anolyte solution does play a role on the performance in a way that the presence of ionic agents in the solution extends the reaction zone and thus increases reaction rates.

\section{Acknowledgements}

This project has received funding from the European Union's Horizon 2020 research and innovation programme "CritCat" under grant agreement No 686053 and from Synfuels China Technology Co. Ltd. We acknowledge M.W.G.M (Tiny) Verhoeven for valuable technical assistance and C.J. (Kees Jan) Weststrate for fruitful discussions.

\section{References}

[1] Sapountzi FM, Westrate CJ, Gracia JM, Niemantsverdriet JW. Electrocatalysts for generation of hydrogen, oxygen and synthesis gas. Prog Energy Combust Sci 2016;58:In Submission. doi:10.1016/j.pecs.2016.09.001.

[2] Carmo M, Fritz DL, Mergel J, Stolten D. A comprehensive review on PEM water electrolysis. Int J Hydrogen Energy 2013;38:4901-34. doi:10.1016/j.ijhydene.2013.01.151.

[3] Ferrero D, Lanzini A, Santarelli M, Leone P. A comparative assessment on hydrogen production from low- and high-temperature electrolysis. Int J Hydrogen Energy 2013;38:3523-36. doi:10.1016/j.ijhydene.2013.01.065. 
[4] Aricò AS, Siracusano S, Briguglio N, Baglio V, Di Blasi A, Antonucci V. Polymer electrolyte membrane water electrolysis: Status of technologies and potential applications in combination with renewable power sources. J Appl Electrochem 2013;43:107-18. doi:10.1007/s10800-012-0490-5.

[5] Acar C, Dincer I. Comparative assessment of hydrogen production methods from renewable and non-renewable sources. Int J Hydrogen Energy 2014;39:1-12. doi:10.1016/j.ijhydene.2013.10.060.

[6] Ju HK, Giddey S, Badwal SPS, Mulder RJ. Electro-catalytic conversion of ethanol in solid electrolyte cells for distributed hydrogen generation. Electrochim Acta 2016;212:744-57. doi:10.1016/j.electacta.2016.07.062.

[7] Coutanceau C, Baranton S. Electrochemical conversion of alcohols for hydrogen production: a short overview. Wiley Interdiscip Rev Energy Environ 2016;5:388-400. doi:10.1002/wene.193.

[8] Halme A, Selkäinaho J, Noponen T, Kohonen A. An alternative concept for DMFC Combined electrolyzer and H2 PEMFC. Int J Hydrogen Energy 2016;41:2154-64. doi:10.1016/j.ijhydene.2015.12.007.

[9] Gutierrez-Guerra N, Jimenez-Vazquez M, Serrano-Ruiz JC, Valverde JL, de LucasConsuegra A. Electrochemical reforming vs. catalytic reforming of ethanol: A process energy analysis for hydrogen production. Chem Eng Process Process Intensif 2015;95:916. doi:10.1016/j.cep.2015.05.008.

[10] Sasikumar G, Muthumeenal A, Pethaiah SS, Nachiappan N, Balaji R. Aqueous methanol eletrolysis using proton conducting membrane for hydrogen production. Int J Hydrogen Energy 2008;33:5905-10. doi:10.1016/j.ijhydene.2008.07.013.

[11] Majone M, Aulenta F, Dionisi D, D'Addario EN, Sbardellati R, Bolzonella D, Beccari M. High-rate anaerobic treatment of Fischer-Tropsch wastewater in a packed-bed biofilm reactor. Water Res 2010;44:2745-52. doi:10.1016/j.watres.2010.02.008.

[12] Xiao Y, Xu HY, Xie HM, Yang ZH, Zeng GM. Comparison of the treatment for isopropyl alcohol wastewater from silicon solar cell industry using SBR and SBBR. Int J Environ 
Sci Technol 2015;12:2381-8. doi:10.1007/s13762-014-0634-8.

[13] dos Reis RGCS, Colmati F. Electrochemical alcohol oxidation: a comparative study of the behavior of methanol, ethanol, propanol, and butanol on carbon-supported PtSn, $\mathrm{PtCu}$, and Pt nanoparticles. J Solid State Electrochem 2016;20:2559-67. doi:10.1007/s10008-016$3323-3$.

[14] Podlovchenko BI, Petry OA, Frumkin AN, Lal H. The behaviour of platinized-platinum electrode in solutions of alcohols containing more than one carbon atom, aldehydes and formic acid. J Electroanal Chem 1966;11:12-25.

[15] Pastor E, Arévalo MC, González S, Arvia AJ. The electroformation and the anodic stripping characteristics of adsorbed residues formed on platinum electrodes from acid solutions containing different alcohols. Electrochim Acta 1991;36:2003-13. doi:10.1016/0013-4686(91)85086-M.

[16] Li N-H, Sun S-G, Chen S-P. Studies on the role of oxidation states of the platinum surface in electrocatalytic oxidation of small primary alcohols. J Electroanal Chem 1997;430:5767. doi:10.1016/S0022-0728(97)00094-6.

[17] Zhang C, Zhu A, Huang R, Zhang Q. Hollow nanoporous Au/Pt core-shell catalysts with nanochannels and enhanced activities towards electro-oxidation of methanol and ethanol. Int J Hydrogen Energy 2014;39:8246-56.

[18] Zhiani M, Majidi S, Rostami H. Comparative study of aliphatic alcohols electrooxidation on zero-valent palladium complex for direct alcohol fuel cells. Int J Hydrogen Energy 2015;40:568-76.

[19] He Q, Shen Y, Xiao K, Xi J. Alcohol electro-oxidation on platinum-ceria/graphene nanosheet in alkaline solutions. Int J Hydrogen Energy 2016;41:20709-19.

[20] Habibi E, Bidad E, Feizbakhsh A, Fazli M. Comparative electrooxidation of C1-C4 alcohols on Pd|CC nanoparticle anode catalyst in alkaline medium. Int J Hydrogen Energy 2014;39:18416-23. doi:10.1016/j.ijhydene.2014.09.049.

[21] Sieben JM, Comignani V, Alvarez AE, Duarte MME. Synthesis and characterization of $\mathrm{Cu}$ core $\mathrm{Pt}-\mathrm{Ru}$ shell nanoparticles for the electro-oxidation of alcohols. Int J Hydrogen 
Energy 2014;39:8667-74.

[22] Take T, Tsurutani K, Umeda M. Hydrogen production by methanol-water solution electrolysis. J Power Sources 2007;164:9-16. doi:10.1016/j.jpowsour.2006.10.011.

[23] Pham AT, Baba T, Shudo T. Efficient hydrogen production from aqueous methanol in a PEM electrolyzer with porous metal flow field: Influence of change in grain diameter and material of porous metal flow field. Int J Hydrogen Energy 2013;38:9945-53. doi:10.1016/j.ijhydene.2013.05.171.

[24] Sethu SP, Ramalinga Viswanathan M, Mani U, Chan SH. Evaluation of impregnated nanocomposite membranes for aqueous methanol electrochemical reforming. Solid State Ionics 2015;283:16-20. doi:10.1016/j.ssi.2015.11.006.

[25] Cloutier CR, Wilkinson DP. Electrolytic production of hydrogen from aqueous acidic methanol solutions. Int J Hydrogen Energy 2010;35:3967-84. doi:10.1016/j.ijhydene.2010.02.005.

[26] Lamy C, Guenot B, Cretin M, Pourcelly G. (Invited) A Kinetics Analysis of Methanol Oxidation under Electrolysis/Fuel Cell Working Conditions. ECS Trans 2015;66:1-12. doi:10.1149/06629.0001ecst.

[27] Guenot B, Cretin M, Lamy C. Clean hydrogen generation from the electrocatalytic oxidation of methanol inside a proton exchange membrane electrolysis cell (PEMEC): effect of methanol concentration and working temperature. J Appl Electrochem 2015;45:973-81. doi:10.1007/s10800-015-0867-3.

[28] Lamy C, Guenot B, Cretin M, Pourcelly G. Kinetics Analysis of the Electrocatalytic Oxidation of Methanol inside a DMFC working as a PEM Electrolysis Cell (PEMEC) to generate Clean Hydrogen. Electrochim Acta 2015;177:352-8. doi:10.1016/j.electacta.2015.02.069.

[29] de la Osa AR, Calcerrada AB, Valverde JL, Baranova EA, de Lucas-Consuegra A. Electrochemical reforming of alcohols on nanostructured platinum-tin catalyst-electrodes. Appl Catal B Environ 2015;179:276-84. doi:10.1016/j.apcatb.2015.05.026.

[30] Muthumeenal A, Pethaiah SS, Nagendran A. Investigation of SPES as PEM for hydrogen 
production through electrochemical reforming of aqueous methanol. Renew Energy 2016;91:75-82. doi:10.1016/j.renene.2016.01.042.

[31] Caravaca A, De Lucas-Consuegra A, Calcerrada AB, Lobato J, Valverde JL, Dorado F. From biomass to pure hydrogen: Electrochemical reforming of bio-ethanol in a PEM electrolyser. Appl Catal B Environ 2013;134-135:302-9. doi:10.1016/j.apcatb.2013.01.033.

[32] Caravaca A, Sapountzi FM, De Lucas-Consuegra A, Molina-Mora C, Dorado F, Valverde JL. Electrochemical reforming of ethanol-water solutions for pure $\mathrm{H}_{2}$ production in a PEM electrolysis cell. Int J Hydrogen Energy 2012;37. doi:10.1016/j.ijhydene.2012.03.062.

[33] Jablonski A, Lewera A. Electrocatalytic oxidation of ethanol on Pt, Pt-Ru and Pt-Sn nanoparticles in polymer electrolyte membrane fuel cell-Role of oxygen permeation. Appl Catal B Environ 2012;115-116:25-30. doi:10.1016/j.apcatb.2011.12.021.

[34] Lamy C, Jaubert T, Baranton S, Coutanceau C. Clean hydrogen generation through the electrocatalytic oxidation of ethanol in a Proton Exchange Membrane Electrolysis Cell (PEMEC): Effect of the nature and structure of the catalytic anode. J Power Sources 2014;245:927-36. doi:10.1016/j.jpowsour.2013.07.028.

[35] De Lucas-Consuegra A, De La Osa AR, Calcerrada AB, Linares JJ, Horwat D. A novel sputtered Pd mesh architecture as an advanced electrocatalyst for highly efficient hydrogen production. J Power Sources 2016;321:248-56. doi:10.1016/j.jpowsour.2016.05.004.

[36] Chen YX, Lavacchi A, Miller H, Bevilacqua M, Filippi J, Innocenti M, Marchionni A, Oberhauser W, Wang L, Vizza F. Nanotechnology makes biomass electrolysis more energy efficient than water electrolysis. Nat Commun 2014;5:4036. doi:10.1038/ncomms5036.

[37] Lamy C, Devadas A, Simoes M, Coutanceau C. Clean hydrogen generation through the electrocatalytic oxidation of formic acid in a Proton Exchange Membrane Electrolysis Cell (PEMEC). Electrochim Acta 2012;60:112-20. doi:10.1016/j.electacta.2011.11.006.

[38] Marshall AT, Haverkamp RG. Production of hydrogen by the electrochemical reforming 
of glycerol-water solutions in a PEM electrolysis cell. Int J Hydrogen Energy 2008;33:4649-54. doi:10.1016/j.ijhydene.2008.05.029.

[39] De Paula J, Nascimento D, Linares JJ. Electrochemical reforming of glycerol in alkaline PBI-based PEM reactor for hydrogen production. Chem Eng Trans 2014;41:205-10. doi:10.3303/CET1441035.

[40] de Paula J, Nascimento D, Linares JJ. Influence of the anolyte feed conditions on the performance of an alkaline glycerol electroreforming reactor. J Appl Electrochem 2015;45:689-700. doi:10.1007/s10800-015-0848-6.

[41] Jonzalez-Cobos J. Baranton S. Coutanceau C. Development of Bismuth-modified PtPd nanocatalysts for the electrochemical reforming of polyols into hydrogen and value-added chemicals. ChemElectroChem 2016;3:1694-704.

[42] De Lucas-Consuegra A, Calcerrada AB, De La Osa AR, Valverde JL. Electrochemical reforming of ethylene glycol. Influence of the operation parameters, simulation and its optimization. Fuel Process Technol 2014;127:13-9. doi:10.1016/j.fuproc.2014.06.010.

[43] Miller, H.A.; Bellini, M.; Vizza, F.; Hasenohrl, C.; Tilley RD. Carbon supported Au-Pd core-shell nanoparticles for hydrogen production by alcohol electroreforming. Catal Sci Technol 2016;6:6870-8.

[44] Sapountzi FM, Divane SC, Tsampas MN, Vayenas CG. Enhanced performance of CO poisoned proton exchange membrane fuel cells via triode operation. Electrochim Acta 2011;56. doi:10.1016/j.electacta.2011.06.012.

[45] Xu W, Scott K, Basu S. Performance of a high temperature polymer electrolyte membrane water electrolyser. J Power Sources 2011;196:8918-24. doi:10.1016/j.jpowsour.2010.12.039.

[46] Marshall A, Børresen B, Hagen G, Tsypkin M, Tunold R. Electrochemical characterisation of $\mathrm{Ir}_{\mathrm{x}} \mathrm{Sn}_{1-\mathrm{x}} \mathrm{O}_{2}$ powders as oxygen evolution electrocatalysts. Electrochim Acta 2006;51:3161-7. doi:10.1016/j.electacta.2005.09.004.

[47] Hinds G, Brightman E. In situ mapping of electrode potential in a PEM fuel cell. Electrochem Commun 2012;17:26-9. doi:10.1016/j.elecom.2012.01.007. 
[48] Liu Z, Wainright JS, Huang W, Savinell RF. Positioning the reference electrode in proton exchange membrane fuel cells: Calculations of primary and secondary current distribution. Electrochim Acta 2004;49:923-35. doi:10.1016/j.electacta.2003.10.004.

[49] Gerteisen D. Realising a reference electrode in a polymer electrolyte fuel cell by laser ablation. J Appl Electrochem 2007;37:1447-54. doi:10.1007/s10800-007-9352-y.

[50] Kaserer S, Rakousky C, Melke J, Roth C. Design of a reference electrode for hightemperature PEM fuel cells. J Appl Electrochem 2013;43:1069-78. doi:10.1007/s10800013-0567-9.

[51] Brightman E, Dodwell J, Van Dijk N, Hinds G. In situ characterisation of PEM water electrolysers using a novel reference electrode. Electrochem Commun 2015;52:1-4. doi:10.1016/j.elecom.2015.01.005.

[52] Stoll T, Zafeiropoulos G, Tsampas MN. Solar fuel production in a novel polymeric electrolyte membrane photoelectrochemical (PEM-PEC) cell with a web of titania nanotube arrays as photoanode and gaseous reactants. Int J Hydrogen Energy 2016;41:17807-17. doi:10.1016/j.ijhydene.2016.07.230.

[53] A. Santasalo-Aarnio, P. Peljo, E. Aspberg KK and TK. Methanol, Ethanol and Isopropanol Performance in Alkaline Direct Alcohol Fuel Cell (ADAFC). ECS Trans 2010;33:1701-14.

[54] Lamy C, Belgsir EM, Léger JM. Electrocatalytic oxidation of aliphatic alcohols: Application to the direct alcohol fuel cell (DAFC). J Appl Electrochem 2001;31:799-809. doi:10.1023/A:1017587310150.

[55] Chu YH, Shul YG. Alcohol crossover behavior in direct alcohol fuel cells (DAFCs) system. Fuel Cells 2012;12:109-15. doi:10.1002/fuce.201100044.

[56] Tamaki T, Yamauchi A, Ito T, Ohashi H, Yamaguchi T. The effect of methanol crossover on the cathode overpotential of DMFCs. Fuel Cells 2011;11:394-403. doi:10.1002/fuce.201000141.

[57] R.M. Modibedi, K.I. Ozoemen MKM. Palladium-based nanocatalysts for alcohol electrooxidation in alkaline media. In: Shao M, editor. Electrocatal. fuel cells A non- low- 
Platin. approach, London: Springer-Verlag; 2013, p. 129-56.

[58] H. Liu JZ, editor. Electrocatalysis of direct methanol fuel cells. Weinheim: Wiley-VCH Verlag GmbH; 2009.

[59] Akhairi MAF, Kamarudin SK. Catalysts in direct ethanol fuel cell (DEFC): An overview. Int J Hydrogen Energy 2016;41:4214-28. doi:10.1016/j.ijhydene.2015.12.145.

[60] Hwang C-M, Ishida M, Ito H, Maeda T, Nakano A, Kato A, Yoshida T. Effect of PTFE contents in the Gas Diffusion Layers of Polymer Electrolyte-based Unitized Reversible Fuel Cells. J Int Counc Electr Eng 2012;2:171-7. doi:10.5370/JICEE.2012.2.2.171.

[61] Zhao Q, Carro N, Ryu HY, Benziger J. Sorption and transport of methanol and ethanol in $\mathrm{H}$ p -na fi on 2012;53:1267-76. doi:10.1016/j.polymer.2012.01.050.

[62] Saito M, Tsuzuki S, Hayamizu K, Okada T. Alcohol and proton transport in perfluorinated ionomer membranes for fuel cells. J Phys Chem B 2006;110:24410-7. doi:10.1021/jp0643496.

[63] Saarinen V, Kreuer KD, Schuster M, Merkle R, Maier J. On the swelling properties of proton conducting membranes for direct methanol fuel cells. Solid State Ionics 2007;178:533-7. doi:10.1016/j.ssi.2006.12.001.

[64] Elliott J, Hanna S, Elliott MS, Cooley GE. The swelling behaviour of perfluorinated ionomer membranes in ethanol/water mixtures. Polymer 2001;42:2251-3. doi:10.1016/S0032-3861(00)00538-3.

[65] Azevedo DC, Lizcano-Valbuena WH, Gonzalez ER. An impedance study of the rate determining step for methanol oxidation on platinum and platinum-ruthenium supported on high surface area carbon. J New Mater Electrochem Syst 2004;7:191-6.

[66] Pierozynski B. On the ethanol electrooxidation reaction on catalytic surfaces of Pt in 0.1 $\mathrm{M} \mathrm{NaOH}$. Int J Electrochem Sci 2012;7:4261-71.

[67] Wang Y, Zou S, Cai W-B. Recent Advances on Electro-Oxidation of Ethanol on Pt- and Pd-Based Catalysts: From Reaction Mechanisms to Catalytic Materials. Catalysts 2015;5:1507-34. doi:10.3390/catal5031507. 
[68] Kamarudin MZF, Kamarudin SK, Masdar MS, Daud WRW. Review: Direct ethanol fuel cells. Int J Hydrogen Energy 2013;38:9438-53. doi:10.1016/j.ijhydene.2012.07.059.

[69] Tierney MJ. Practical examples of polymer-based chemical sensors. In: Taylor, Richard F.; Schultz JS, editor. Handb. Chem. Biol. sensors, IOP Publishing Ltd; 1996, p. 356.

[70] Jing M, Jiang L, Yi B, Sun G. Comparative study of methanol adsorption and electrooxidation on carbon-supported platinum in acidic and alkaline electrolytes. J Electroanal Chem 2013;688:172-9. doi:10.1016/j.jelechem.2012.10.028.

[71] Lai SCS, Kleijn SEF, Öztürk FTZ, Van Rees Vellinga VC, Koning J, Rodriguez P, Koper M.T.M. Effects of electrolyte $\mathrm{pH}$ and composition on the ethanol electro-oxidation reaction. Catal Today 2010;154:92-104. doi:10.1016/j.cattod.2010.01.060.

[72] Tripkovic AV, Popovic KD, Grgur BN, Blizanac B, Ross PN, Markovic NM. Methanol electrooxidation on supported Pt and PtRu catalysts in acid and alkaline solutions. Electrochim Acta 2002;47:3707-14. doi:10.1016/S0013-4686(02)00340-7.

[73] Prapainainar, C.; Holmers SM. Proton conductivity of Nafion membrane in actual direct methanol fuel cell operation. Sustain. Energy Build. Res. Adv. Spec. Ed. - Mediterr. Green Energy Forum 2013, n.d., p. Vol.2 : pp.31-35-23.

[74] Lamy C, Lima A, LeRhun V, Delime F, Coutanceau C, Léger JM. Recent advances in the development of direct alcohol fuel cells (DAFC). J Power Sources 2002;105:283-96. doi:10.1016/S0378-7753(01)00954-5.

[75] Aramata A.; Matsuda M. Platinum Alloy Electrodes Bonded to Solid Polymer Electrolyte for Enhancement of Methanol Electro-oxidation and Its Reaction Mechanism. J Electrochem Soc 1991;138:1949-57.

[76] Gootzen JFE, Wonders H, Visscher W, van Veen J. R. Adsorption of C-3 Alcohols, 1Butanol, and Ethene on Platinized Platinum As Studied with FTIRS and DEMS. Langmuir 1997;13:1659-67. doi:10.1021/la960991n.

[77] Lai SC, Koper MT. Electro-oxidation of ethanol and acetaldehyde on platinum singlecrystal electrodes. Faraday Discuss 2008;140:399416. doi:10.1039/B814058H. 
[78] Lai SCS, Kleyn SEF, Rosca V, Koper MTM. Mechanism of the dissociation and electrooxidation of ethanol and acetaldehyde on platinum as studied by SERS. J Phys Chem C 2008;112:19080-7. doi:10.1021/jp807350h.

[79] Sun S, Yang D, Tian Z. In situ FTIR studies on the adsorption and oxidation of n-propanol and iso propanol at a Pt electrode in sulphuric acid solutions. J Electroanal Chem 1990;289:177-87.

[80] Wang J, Wasmus S, Savinell RF. Evaluation of Ethanol, 1-Propanol, and 2-Propanol in a Direct Oxidation Polymer-Electrolyte Fuel Cell. J Electrochem Soc 1995;142:4218. doi:10.1149/1.2048487.

[81] Sitta E, Santos AL, Nagao R, Varela H. Nanogravimetric study of the complex voltammetric response in the electro-oxidation of methanol on platinum. Electrochim Acta 2009;55:404-9. doi:10.1016/j.electacta.2009.02.069.

[82] Cai X, Schell M. Observation of bistability in cyclic voltammetric experiments on ethanol, propanol, butanol and formic acid/formate. Electrochim Acta 1992;37:673-80. doi:10.1016/0013-4686(92)80070-3.

[83] Parida GR, Schell M. Coexisting Cyclic Voltammograms. J Phys Chem 1991;95:2356-61. doi:10.1021/j100159a044.

[84] Varela H, Krischer K. Deciphering the origin of high-order periodic and aperiodic cyclic voltammetric responses during oxidation processes on platinum. J Phys Chem B 2002;106:12258-66. doi:10.1021/jp026673g.

[85] Cheng Y, Liu Y, Cao D, Wang G, Gao Y. Effects of acetone on electrooxidation of 2propanol in alkaline medium on the Pd/Ni-foam electrode. J Power Sources 2011;196:3124-8. doi:10.1016/j.jpowsour.2010.12.008. 